economic strata and are often residents of rural areas. Diet lacks high-class proteins and consists mostly of cereals and a small quantity of pulses. Very low levels of total serum proteins and albumin are noted in hospitalized patients. The presumptive evidence of protein malnutrition and deprivation is strong, unlike the cryptogenic types in Britain.

Less than a quarter of patients give a history of jaundice. Presuming that all jaundice in the past is due to infectious hepatitis, the actual percentage may be much less, as pallor of anaemia due to ankylostomiasis is often wrongly described as icterus by these patients, as they are not good witnesses of their past events. Further, infectious hepatitis is more common in cities, but cirrhotics are mostly drawn from villages. It is therefore likely that viral hepatitis may be of even lesser importance in causation of cirrhosis in India than in England.

A majority of patients, 55 to $75 \%$, show a post-necrotic pattern of hepatic tissue.-I am, etc.,

Moti Lall Nehru Medical College,

B. L. Agarwal.

Allahabad, India.

\section{Folate Requirement in Pregnancy}

SIR,-The detailed investigations reported by Dr. I. Chanarin and others (18 May, pp. 390 and 394) are clearly of great importance in further defining the pathogenesis of folic-acid deficiency in pregnancy as an equation of supply and demand. We have recently completed a somewhat similar investigation where serial whole-blood folate levels were followed throughout pregnancy and the puerperium in patients either on iron alone or on iron plus $330 \mu \mathrm{g}$. of folic acid a day. Few low whole-blood or red-cell folate values were found at the time of delivery in the group on iron alone, but by six weeks postpartum a sharp fall had occurred, with the median whole-blood folate value for the group lying below the lower limit of our normal controls but within the range found in overt megaloblastic anaemia.

We have interpreted this unexpected finding as being due to the delay with which the redcell (or whole-blood) folate levels reflect the folate stores, this in turn being due to the stability of the intra-erythrocytic folate and the prolonged survival of erythrocytes in the circulation, as pointed out by Dr. Chanarin and by others. ${ }^{2}$ Tests of the red-cell folate at 38 weeks, as by Dr. Chanarin's group, or of the whole-blood folate at 37-39 weeks, as by Hansen and Rybo, ${ }^{2}$ are therefore likely to reflect the average state of folate balance pertaining over the preceding three months (or 110 days).

The finding of much lower levels at six weeks after delivery suggested to us that maximum folate depletion usually occurred in the last few weeks of pregnancy and in the early post-partum period. This would not be unreasonable if foetal growth, bloodloss at delivery, and lactation were important factors in maternal folate utilization. The finding of a normal red-cell folate at 37-39 weeks by Hansen and $\mathrm{Rybo}^{2}$ and at 38 weeks by Chanarin et al. after supplementation by $100 \mu \mathrm{g}$. a day may indicate that this dose is adequate to meet requirements up to 30 or 32 weeks' gestation while still leaving it an open question whether this dose will always prove adequate over the period of delivery and the puerperium.

Our previous investigation, utilizing the post-partum serum folate level, ${ }^{3}$ and the more recent work, utilizing the six-week post-partum whole-blood folate level, suggest that in the Glasgow population $300 \mu \mathrm{g}$. a day is closer to the maximum requirements at the later stages of pregnancy. This dose, however, appears to be in excess of daily requirements during the earlier stages of pregnancy, since excessively high red-cell folate levels were found at term on this dose. As explained in your leading article (18 May, p. 377), a larger prophylactic dose is required for those patients with unusually low dietary intakes, and this fact may also introduce regional variations in apparent requirements as judged by this type of investigation.

I must also point out that the reference in Dr. Chanarin's paper to whole-blood folate levels in patients on various folic acid supplements found by $\mathrm{me}^{4}$ is unfortunately erroneous. The whole-blood folate levels reported in my paper (Table III) referred to tests on the 6-weeks-old babies of mothers on these supplements. It is true that a maternal supplement of $100 \mu \mathrm{g}$. a day caused no detectable elevation of the babies' wholeblood folate, but that a very slight elevation was found when this was $300 \mu \mathrm{g}$. a day.I am, etc.,

\section{WILLOUGHBY. \\ Queen \\ Queen Mother's Hospital,
Yorkhill, Glasgow C.3. \\ REPERENCES \\ Streiff, R. R., and Little, A. B., New Engl. F. Med., 1967, 276, 776 . \\ Hansen, H. A., and Rybo, G., Acta obstet. gynec. scand. 1967, 46, Suppl. No. 7, 107 \\ med 7,1966 . 1568 and Jewell, F. J., Brit. med. F., 1966, 2, 1568 \\ 503.}

\section{Low-dosage Oral Progestogen}

Sir,-Continuous low-dosage progestogen therapy is a current subject for research into "contraceptive pill" preparations, as exemplified by the paper from Dr. J. Zañartu and others (4 May, p. 263). So that the records of the subject can be kept in order I draw attention to Table II in the above article (p. 264).

The following calculations are based on the data given in the paper:

(1) There was a total of 24 pregnancies in 3,400 observed months.

\section{4 pregnancies in 3,400 months}

$$
24
$$

$=-\frac{24}{3,400}$ pregnancies per 1 woman month

$=\frac{24 \times 12}{3,400}$ pregnancies per 1 woman year

$24 \times 12 \times 100$ pregnancies per 100 woman $=\frac{24 \times 12 \times 100}{3,400}$ years

$=8.5$ pregnancies per 100 woman years, not 6.1 as inferred in Table II.

(2) If one considers the 11 pregnancies which occurred due to omission of the pills a similar calculation gives 3.9 pregnancies per 100 woman years, not 2.8 as noted in Table II.

(3) The 13 pregnancies due to method failure can be calculated to be equivalent to 4.6 pregnancies per 100 woman years, not 3.3 as noted in Table II.

Indeed, the title of Table II is also somewhat misleading in an article about the inhibition of fertility with a progestogen. It would seem more appropriate to entitle the Table " Failure of Antifertility Effect" rather than "Recovery of Fertility." These are of course minor points of little importance to the general content of the paper, but they are nevertheless pertinent.-I am, etc.,

$$
\begin{aligned}
& \text { Royal Infirmary, } \\
& \text { Glasgow. }
\end{aligned}
$$

\section{Brand Names}

SIR,-With reference to your leading article (30 March, p, 781), any reasonable proposal likely to decrease the multiplicity of drug names and to facilitate the identification of pharmaceutical preparations is most welcome. However, usage of generic names would be more common if they were less cumbersome and therefore more easily remembered. Compare, for instance, the generic name ethyl biscoumacetate with its trade equivalent Tromexan, or phenoxybenzamine hydrochloride with Dibenzyline, or diphenhydramine hydrochloride with Benadryl. Surely an aspect in the choice of generic names should be the consideration whether they can be conveniently prescribed in a busy practice.

If it is not always easy to find the generic names which correspond to British and American brand names the problem is much greater with the foreign-language literature, where lists of brand names are often not readily available if they exist at all. This makes it difficult or impossible to understand articles in western, and still more so in eastern, European journals. It would be a great step forward if editors of journals agreed to include in all papers the generic names of drugs mentioned as adopted in, say, the U.S. and in one of the western European countries. When a generic name is not available the chemical formula should be given.I am, etc.

\section{Department of Pharmacology, dassah Medical School Jerusalem, Israel.}

\section{Gender and Sex}

SIR,-Of course I agree with Dr. D. H Smyth (11 May, p. 368) that the words "sex" and "gender" are not facultatively interchangeable. But even the grammarians are, or were, not always consistent. When Latin was a sine qua non for entry into a medical school some of us must have chanted from Allen's Latin Grammar: " Common are to either sex, artifex and opifex. ..." I never knew, nor do I now, the meaning of opifex.-I am, etc.,

Liverpool.

\section{A. McKie ReID.}

** Opifex (from opus facere, to do work) means "workman" or, presumably, "working-woman."-ED., B.M.f.

SIR,-I sympathize with Professor D. H. Smyth's complaint (11 May, p. 368) about my phrase "young of both genders"; " of both sexes" would have been more conventional, but not necessarily more correct. For he is wrong in suggesting that the word gender "was invented by grammarians." The Oxford English Dictionary gives its first 